\title{
Effects of Induced Clinical Mastitis During Preovulation on Endocrine and Follicular Function,
}

\author{
M. E. Hockett, ${ }^{1}$ R. A. Almeida, ${ }^{1}$ N. R. Rohrbach, ${ }^{1}$ S. P. Oliver, ${ }^{1}$ \\ H. H. Dowlen, ${ }^{2}$ and F. N. Schrick ${ }^{1}$ \\ ${ }^{1}$ Department of Animal Science, University of Tennessee, Knoxville 37996-4574 \\ ${ }^{2}$ University of Tennessee Dairy Experiment Station, Lewisburg 37091
}

\begin{abstract}
The objective of the study was to determine if experimentally induced clinical mastitis before ovulation resulted in alterations of endocrine function, follicular growth, or ovulation. On d 8 (estrus $=\mathrm{d} 0$ ), cows were challenged (TRT; $\mathrm{n}=19$ ) with Streptococcus uberis or were not challenged (control; $n=14$ ). Forty-eight hours after induction of luteal regression on d 12 , blood samples were collected to determine estradiol-17 $\beta, \mathrm{LH}$ pulse frequency, and occurrence of the LH surge. Ovaries were scanned to monitor follicular growth and ovulation. Cows with clinical mastitis $(\mathrm{n}=12)$ had elevated rectal temperatures, somatic cell counts, and mammary scores. Estrus and ovulation occurred in 4 of 12 clinically infected cows and in all control cows. Cows that were challenged but did not develop clinical mastitis $(n=5)$ displayed estrus and ovulated. Due to differences in expression of estrus, cows were further subdivided for analyses into 4 groups: control, TRT-EST (infected cows that displayed estrus; $n=4$ ), TRT-NOEST (infected cows that did not display estrus; $n=8$ ), and NOMAS (cows that were inoculated but did not develop mastitis; $\mathrm{n}=4$ ). Ovulation rate was $100 \%$ for $\mathrm{CON}$, NOMAS, and TRT-EST compared with 0\% for TRTNOEST cows. Size of the ovulatory follicle ("presumed" ovulatory follicle in TRT-NOEST cows) was similar for all groups. Frequency of LH pulses was decreased in TRT-NOEST compared with CON, TRT-EST, and NOMAS. Estradiol- $17 \beta$ increased over time in CON, NOMAS, and TRT-EST cows, but did not increase in TRTNOEST cows. Cows with clinical mastitis may exhibit estrus and ovulate normally or have disruptions in normal physiology including decreased LH pulsatility, absence of an LH surge and estrous behavior, suppressed estradiol-17 $\beta$, and failure to ovulate.
\end{abstract}

(Key words: estrus, dairy cow, luteinizing hormone, mastitis)

Received October 29, 2004.

Accepted March 7, 2005.

Corresponding author: F. Neal Schrick; e-mail: fschrick@utk.edu.
Abbreviation key: $\mathbf{B U N}=$ blood urea nitrogen, $\mathbf{C O N}=$ unchallenged control cows, $\mathbf{E}_{\mathbf{2}}=$ estradiol-17 $\beta$, NOMAS = cows challenged with Strep. uberis that did not develop mastitis, $\mathbf{P}_{\mathbf{4}}=$ progesterone, $\mathbf{T R T}=$ cows challenged with Strep. uberis, TRT-EST = cows that were challenged, became clinical, and displayed estrus, TRT-NOEST = cows that were challenged, became clinical, and did not display estrus.

\section{INTRODUCTION}

Mastitis has been described as the most economically imposing disease facing dairy producers in the United States, costing an estimated $\$ 2$ billion annually (DeGraves and Fetrow, 1993). Aside from the decrease in milk production and alterations in milk composition, studies from our laboratory have indicated an association between reproductive failure and clinical mastitis in lactating dairy cows. Days to first service, days open, and services per conception were significantly increased for cows with clinical mastitis compared with cows without mammary infection or in which infection occurred after establishment of pregnancy (Barker et al., 1998; Schrick et al., 2001).

Elevated concentrations of cortisol and 13, 14-dihydro-15-keto $\mathrm{PGF}_{2 \alpha}$ as well as altered interestrous intervals have been reported in cows with clinical mastitis during the luteal phase of the estrous cycle (Moore et al., 1991; Hockett et al., 2000). Cullor (1990) suggested that endotoxin might induce luteolysis and influence conception and early embryonic survival by release of inflammatory mediators. Moore and O'Connor (1993) hypothesized that gram-negative mastitis pathogens may stimulate production of $\mathrm{PGF}_{2 \alpha}$ and cause luteal regression.

Barker et al. (1998) and Schrick et al. (2001) reported that gram-negative and gram-positive mastitis pathogens were associated with similar decreases in reproductive efficiency of lactating dairy cows. Furthermore, occurrence of subclinical mastitis had similar detrimental effects on reproductive performance as clinical mastitis (Schrick et al., 2001). More recently, our laboratory has determined that cows with clinical mastitis during 
the preovulatory period had decreased expression of estrus, periods of anestrus, and decreased pregnancy rates (Hockett et al., 2002). Feed intakes may also be decreased in animals experiencing clinical infection, thereby altering energy metabolites and allowing for interruption in reproductive function.

Mechanisms by which mastitis interferes with expression of estrus are not well understood. Identification of such mechanisms may lead to the development of treatment protocols to minimize additional costs of mastitis associated with decreased reproductive performance. Therefore, the objective of the present study was to determine if experimental induction of clinical mastitis before ovulation interrupted the hypothalamopituitary-ovarian axis or feed intake, thus altering endocrine function, follicular growth, and ovulation of the preovulatory follicle.

\section{MATERIALS AND METHODS}

\section{General}

Cows were allocated randomly by stage of lactation, lactation number, and milk production before initiation of each replicate of experiment ( $\mathrm{n}=2$ replicates $)$ to serve as control (CON; $\mathrm{n}=14$ ) or mastitic-challenged (TRT; $\mathrm{n}=19$ ) cows. Increased numbers of cows were needed for the experimentally challenged group to have comparable number of clinically infected TRT cows as controls. All cows tested negative for presence of major mastitis pathogens on 2 occasions 1 wk apart before allotment to treatment groups. Estrus was synchronized with 2 intramuscular injections of $25 \mathrm{mg}$ of $\mathrm{PGF}_{2 \alpha}$ (Lutalyse, Pharmacia Animal Health, Kalamazoo, MI) administered at 14-d intervals. Before initiation of treatment, cows were trained to Calan gates and were allowed a 2-wk adjustment period. Feed intake was recorded daily for each animal to observe if major changes in intake occurred during the study period. Cows were fed a corn silage-based ration.

\section{Bacterial Inoculum Preparation}

Streptococcus uberis strain 888 was revived from storage at $-80^{\circ} \mathrm{C}$ by thawing in a water bath at $37^{\circ} \mathrm{C}$. The thawed bacterial suspension $(20 \mu \mathrm{L})$ was streaked onto blood agar plates and incubated overnight at $37^{\circ} \mathrm{C}$. After incubation, 3 colonies were selected using a sterile loop and inoculated into $20 \mathrm{~mL}$ of Todd-Hewitt broth and incubated for $6 \mathrm{~h}$ at $37 \pm 1.0^{\circ} \mathrm{C}$. Following incubation, broth culture was diluted in sterile PBS to provide an inoculum of 600 to $1000 \mathrm{cfu} / \mathrm{mL}$.

\section{Challenge Inoculum Administration}

Within $0.5 \mathrm{~h}$ after the p.m. milking ( $4 \mathrm{~d}$ before the second injection of $\mathrm{PGF}_{2 \alpha}$; Figure 1), $5 \mathrm{~mL}$ of inoculum containing 3000 to 5000 cfu of Strep. uberis in sterile PBS was infused into 2 uninfected mammary glands of each cow in the TRT group ( $\mathrm{n}=7$ and 12 in replicates 1 and 2, respectively). Initiation of bacterial challenge $4 \mathrm{~d}$ before the second injection of $\mathrm{PGF}_{2 \alpha}$ was performed with the planned result of cows displaying clinical mastitis on the day of, or day following, $\mathrm{PGF}_{2 \alpha}$ administration (approximately $2 \mathrm{~d}$ before estrus). This time was chosen to allow cortisol to reach peak values before the preovulatory rise in estradiol $\left(\mathbf{E}_{2}\right)$ and $\mathrm{LH}$ as well as exposing the developing oocyte to inflammatory mediators before ovulation.

Number of bacteria was determined by viable plate count on blood agar before and after inoculation, and inoculum was maintained at room temperature up to the time of inoculation. Selection of inoculum volume and total number of colony-forming units was based on results of several previous studies when developing the Strep. uberis challenge model in early and midlactating cows (Hockett et al., 2000). The bacterial suspension was infused using sterile disposable syringes fitted with sterile disposable teat cannulas. Full insertion of the teat cannula through the streak canal was used. Before inoculation, teat ends were dipped in a teat disinfectant, teats were dried with disposable paper towels, and teat ends were cleaned thoroughly with swabs containing $70 \%$ ethanol. The infused inoculum was massaged upward into the gland cistern. The teat was immersed in postmilking teat disinfectant following infusion. After challenge, cows were monitored closely and supportive therapy initiated promptly if an acute infection occurred.

Quarter foremilk samples for microbiological evaluation were obtained aseptically, as described below, from all mammary glands of challenged cows immediately before inoculation, daily for $7 \mathrm{~d}$, and at $\mathrm{d} 14$ and 21 . Cows in the untreated control (CON) group were sampled at the same intervals as challenged cows.

\section{Microbiological Evaluation of Milk Samples}

Samples of foremilk from quarters of cows were collected aseptically. Before sample collection, teats of cows were cleaned immersed in a premilking disinfectant, cleaned with individual disposable paper towels, and sanitized with swabs containing isopropyl alcohol. Milk samples were examined following procedures recommended by the National Mastitis Council and as described by Oliver et al. (1994). Briefly, foremilk samples $(10 \mu \mathrm{L})$ from each quarter were plated onto one quadrant of a trypticase soy agar plate supplemented 

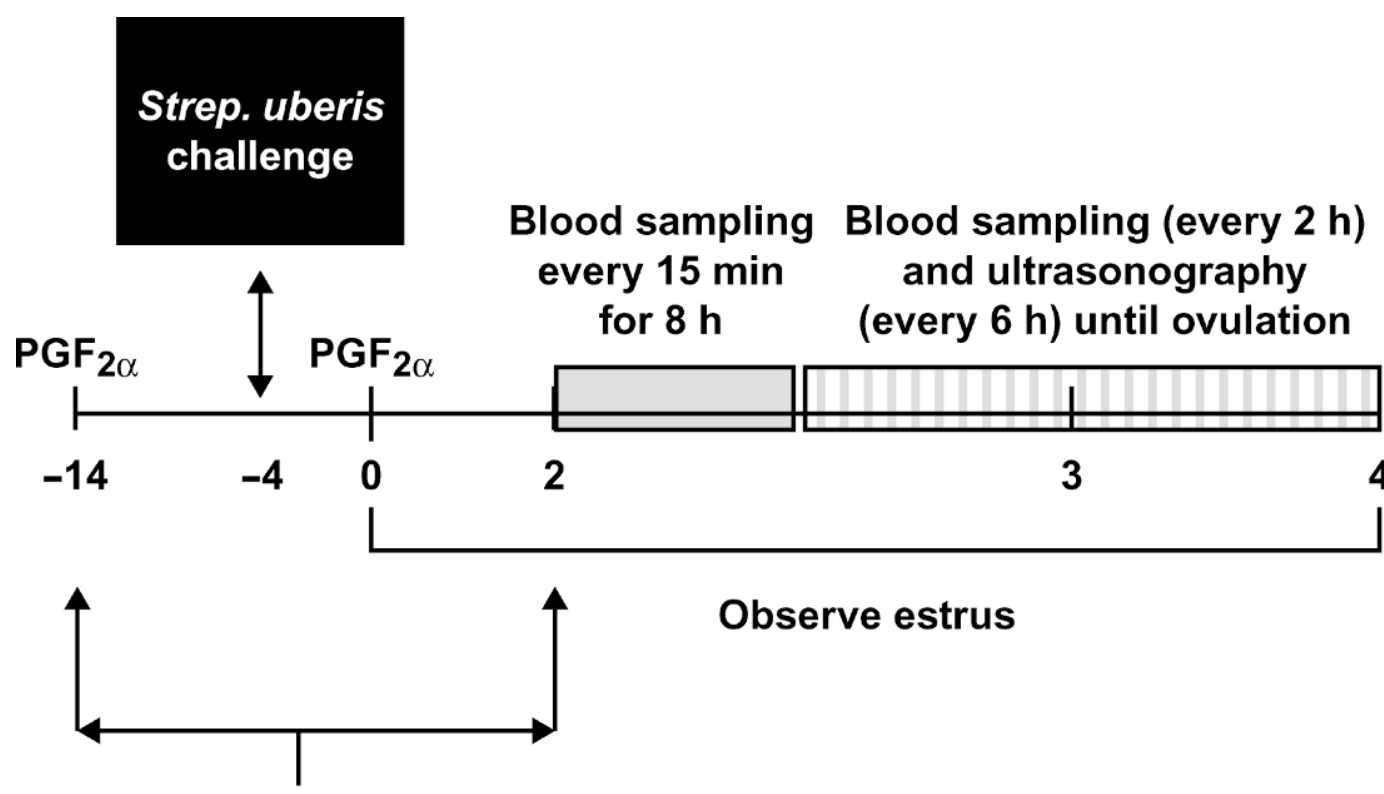

\section{Daily ultrasonography}

Figure 1. Schematic representation of experimental design for TRT (experimentally challenged to induce clinical mastitis) and CONTROL (unchallenged) cows.

with 5\% defibrinated sheep blood (Laboratory Supply, Nashville, TN). Plates were incubated at $37^{\circ} \mathrm{C}$ and bacterial growth was observed and recorded at 24 -h intervals for $3 \mathrm{~d}$. Bacteria on primary culture medium were identified tentatively according to colony morphologic features, hemolytic characteristics, and catalase test. Isolates identified presumptively as staphylococci were tested for coagulase by the tube coagulase method. Isolates identified presumptively as streptococci were evaluated initially for growth in $6.5 \% \mathrm{NaCl}$, hydrolysis of esculin, and CAMP-reaction. Streptococcal organisms were identified to the species level using the API 20 Strep System (bioMerieux Vitek, Inc., Hazelwood, MO) upon first and last isolation of the organism from experimentally infected mammary glands. Streptococcal organisms isolated between the first and last isolation were identified by sodium hippurate hydrolysis for Strep. uberis. All other Streptococcus and Enterococcus species were identified using the API 20 Strep System (bioMerieux Vitek, Inc.) for subsequent isolates. Gramnegative isolates were plated on MacConkey's agar (Becton Dickinson Microbiology Systems, Sparks, MD) and evaluated by the following biochemical tests: triple sugar iron, urea, oxidase, motility, indole, and ornithine decarboxylase.

\section{Clinical Observations}

Clinical assessment of animals was performed before experimental bacterial challenge and when milk sam- ples were collected. Clinical status of mammary glands and appearance of milk were evaluated by qualified farm personnel at each milking using the following scheme: 1 = normal mammary gland and normal milk, 2 = normal mammary gland and slight alterations in milk (a few flakes), $3=$ abnormal mammary gland and abnormal milk (clots, clumps, changes in milk color), and $4=$ swollen mammary gland, abnormal milk, and systemic signs (hyperthermia, depression, dullness) of infection. Cows that developed clinical mastitis were monitored closely and antibiotic treatment was initiated $7 \mathrm{~d}$ postchallenge.

Clinical mastitis was diagnosed when Strep. uberis was isolated from challenged mammary glands at any milking postchallenge and the challenged mammary gland had a mastitis score of 2 or 3 for 2 consecutive milkings during the 7-d postchallenge period. Acute clinical mastitis was scored for experimentally challenged mammary glands when Strep. uberis was isolated from the challenged mammary gland at any milking postchallenge, milk from the challenged mammary gland had a mastitis score of 4 for 2 consecutive milkings during the 7-d postchallenge period, and the cow was hyperthermic. Rectal temperatures were obtained daily throughout the study at milking time for all cows.

\section{Determination of Estrous Expression}

All cows were evaluated 3 times daily to determine onset of estrus. Cows were monitored every $2 \mathrm{~h}$ during 
intensive blood sampling to determine estrous behavior. Cows had access to a dirt lot and bedded pack area during evaluation for estrus. Due to differences in expression of estrus, cows were further subdivided for analyses into 4 groups: control, TRT-EST (infected cows that displayed estrus; $n=4$ ), TRT-NOEST (infected cows that did not display estrus; $n=8$ ), and NOMAS (cows inoculated but did not develop mastitis; $\mathrm{n}=4)$.

\section{Blood Collection}

Blood samples (10 mL) were collected daily via jugular venipuncture to evaluate progesterone $\left(\mathbf{P}_{4}\right)$, cortisol, blood urea nitrogen (BUN), NEFA, and insulin concentrations from all experimentally infected and control cows. At time of second $\mathrm{PGF}_{2 \alpha}$ injection, TRT and CON cows (across 2 replicates; Figure 1) had jugular veins catheterized as described by Hockett et al. (2000) to allow for frequent sample collection and reduced handling stress on animals. Catheters were flushed immediately before and after each collection with heparinized saline $(200 \mathrm{IU} / \mathrm{mL})$ to maintain catheter function throughout the experimental period. Samples were collected every 15 min from 48 to $56 \mathrm{~h}$ following $\mathrm{PGF}_{2 \alpha}$ injection (d 0) to evaluate LH pulse frequency. Following the intensive blood sample collection period, samples were collected every $2 \mathrm{~h}$ until ovulation to determine the LH surge and preovulatory rise in $\mathrm{E}_{2}$. Blood samples were centrifuged $(2500 \times \mathrm{g})$; sera were harvested and stored at $-20^{\circ} \mathrm{C}$ until assayed.

\section{Ultrasonography of Ovarian Structures}

All cows had ovaries scanned (Aloka 500 unit, 7.5$\mathrm{MHz}$ linear transducer, Corometrics Medical Systems, Inc., Wallingford, CT) to ascertain development of the ovulatory follicle as follows: 1) ovaries were scanned daily beginning at intramammary inoculation to ascertain follicular and luteal characteristics (Seals et al., 1996), and 2) every $6 \mathrm{~h}$ beginning at visual observation of estrus until ovulation occurred (disappearance of the ovulatory follicle). Diagrams of locations and measurements of follicles $\geq 5 \mathrm{~mm}$ in diameter and corpora lutea were made for each ovary at the time of ultrasonography (Knopf et al., 1989).

\section{Assays for Hormones and Metabolic Parameters}

Samples were analyzed for LH by procedures described by Moura and Erickson (1997) with a sensitivity of $0.03 \mathrm{ng} / \mathrm{mL}$, with intra- and interassay CV of 6.5 and $15 \%$. Concentrations of $\mathrm{E}_{2}$ (Moura and Erickson, 1997) were determined on serum samples utilizing antibody for $\mathrm{E}_{2}$ supplied by Manson (Lilly Research Laboratories, Indianapolis, IN). Sensitivity of the $\mathrm{E}_{2}$ assay was 0.15 $\mathrm{pg} / \mathrm{mL}$ with intra- and interassay CV of 20 and $4 \%$, respectively. Concentrations of cortisol (Hockett et al., 2000), $\mathrm{P}_{4}$ (Seals et al., 1998), and insulin (Fazio et al., 1999) in serum were determined using solid phase radioimmunoassays (Diagnostic Products Corp., Los Angeles, CA). Sensitivity of the cortisol assay was 2 $\mathrm{ng} / \mathrm{mL}$ with intra- and interassay CV of 10 and $0.2 \%$, respectively. Sensitivity of the progesterone assay was $0.02 \mathrm{ng} / \mathrm{mL}$ with intra- and interassay CV of 8 and $4 \%$, respectively. Concentrations of BUN and NEFA were determined in serum utilizing spectrophotometry as validated in our laboratory (Fazio et al., 1999). Blood urea nitrogen concentrations were determined utilizing a commercial kit with sensitivity of $15 \mathrm{mg} / \mathrm{dL}$, intraassay CV of 6\%, and interassay CV of $12 \%$ (Sigma Diagnostics, St. Louis, MO). Concentrations of NEFA were determined using a NEFA-C kit with a sensitivity of $0.125 \mathrm{mEq} / \mathrm{L}$ and intra- and interassay CV of 5 and $27 \%$, respectively (Wako Pure Chemical Industries, Osaka, Japan). All assays are validated and currently used in our laboratory.

\section{Statistical Analyses}

Patterns of $\mathrm{P}_{4}, \mathrm{E}_{2}, \mathrm{LH}, \mathrm{BUN}, \mathrm{NEFA}$, insulin, cortisol, SCC, feed intake, LH maximum, LH pulse frequency, rectal temperature, and mastitis (mammary) score were analyzed by least squares ANOVA for a randomized block with repeated measures. Times from $\mathrm{PGF}_{2 \alpha}$ to estrus, $\mathrm{PGF}_{2 \alpha}$ to ovulation, $\mathrm{PGF}_{2 \alpha}$ to $\mathrm{LH}$ maximum, estrus to ovulation, and differences in size of ovulatory follicles were analyzed by least squares ANOVA for a randomized block. Size of "presumed" ovulatory follicles in cows that were challenged, became clinically infected, but did not display estrus (TRT-NOEST) was determined by calculating average time of ovulation in CON cows and using that time for selection of the largest follicle in TRT-NOEST cows. Concentrations of estradiol- $17 \beta$ were normalized for cows that displayed estrus (CON and TRT-EST) for the $24 \mathrm{~h}$ period before maximum observed LH release. Due to absence of estrus and LH surge in TRT-NOEST, concentrations of estradiol-17 $\beta$ were calculated for TRT-NOEST based upon the average time of $\mathrm{LH}$ maximum in CON cows (82 h following $\mathrm{PGF}_{2 \alpha}$ ). Pulse frequency of $\mathrm{LH}$ was determined as described by Schrick et al. (1990) with modifications. Briefly, mean LH concentrations were established for each 8-h period with a pulse defined as a point $>0.5$ standard deviations above the mean. Differences in estrous expression and ovulation rates were determined by $\chi^{2}$ analysis. The Mixed procedure (SAS Institute, 1996) was used for all analyses. 
Table 1. Clinical assessment of mastitis in experimentally challenged and control animals.

\begin{tabular}{|c|c|c|c|c|c|c|c|c|}
\hline \multirow[b]{2}{*}{ Parameter $^{2}$} & \multicolumn{8}{|c|}{ Day $^{1}$} \\
\hline & d 0 & $\mathrm{~d} 1$ & $\mathrm{~d} 2$ & d 3 & d 4 & d 5 & d 6 & d 7 \\
\hline \multicolumn{9}{|c|}{ Mammary score ${ }^{3}$} \\
\hline $\mathrm{CON}$ & $1.0^{\mathrm{a}}$ & $1.0^{\mathrm{a}}$ & $1.0^{\mathrm{a}}$ & $1.0^{\mathrm{a}}$ & $1.0^{\mathrm{a}}$ & $1.0^{\mathrm{a}}$ & $1.0^{\mathrm{a}}$ & $\mathrm{NA}^{4}$ \\
\hline NOMAS & $1.0^{\mathrm{a}}$ & $1.0^{\mathrm{a}}$ & $1.0^{\mathrm{a}}$ & $1.0^{\mathrm{a}}$ & $1.0^{\mathrm{a}}$ & $1.0^{\mathrm{a}}$ & $1.0^{\mathrm{a}}$ & NA \\
\hline TRT-EST & $1.0^{\mathrm{a}}$ & $1.0^{\mathrm{a}}$ & $1.0^{\mathrm{a}}$ & $2.0^{\mathrm{bc}}$ & $2.0^{\mathrm{bc}}$ & $1.8^{\mathrm{bc}}$ & $2.8^{\mathrm{d}}$ & NA \\
\hline TRT-NOEST & $1.0^{\mathrm{a}}$ & $1.1^{\mathrm{a}}$ & $1.4^{\mathrm{a}}$ & $1.9^{\mathrm{bc}}$ & $2.8^{\mathrm{d}}$ & $3.1^{\mathrm{d}}$ & $3.7^{\mathrm{e}}$ & NA \\
\hline \multicolumn{9}{|l|}{$\mathrm{SCC}^{5}$} \\
\hline $\mathrm{CON}$ & $4.4^{\mathrm{a}}$ & $4.6^{\mathrm{a}}$ & $4.7^{\mathrm{a}}$ & $4.4^{\mathrm{a}}$ & $4.5^{\mathrm{a}}$ & $4.5^{\mathrm{a}}$ & $4.5^{\mathrm{a}}$ & $4.5^{\mathrm{a}}$ \\
\hline NOMAS & $4.5^{\mathrm{a}}$ & $4.8^{\mathrm{a}}$ & $4.8^{\mathrm{a}}$ & $4.6^{\mathrm{a}}$ & $4.9^{\mathrm{a}}$ & $4.8^{\mathrm{a}}$ & $4.9^{\mathrm{a}}$ & $4.7^{\mathrm{a}}$ \\
\hline TRT-EST & $3.8^{\mathrm{a}}$ & $4.4^{\mathrm{a}}$ & $4.9^{\mathrm{a}}$ & $5.5^{\mathrm{b}}$ & $6.0^{\mathrm{c}}$ & $6.2^{\mathrm{c}}$ & $7.0^{\mathrm{d}}$ & $7.2^{\mathrm{d}}$ \\
\hline TRT-NOEST & $4.4^{\mathrm{a}}$ & $4.7^{\mathrm{a}}$ & $5.3^{\mathrm{b}}$ & $5.5^{\mathrm{b}}$ & $5.7^{\mathrm{bc}}$ & $5.9^{\mathrm{c}}$ & $6.1^{\mathrm{c}}$ & $6.8^{\mathrm{d}}$ \\
\hline \multicolumn{9}{|c|}{ Rectal temperature $^{6}$} \\
\hline $\mathrm{CON}$ & $38.0^{\mathrm{ab}}$ & $38.7^{\text {cd }}$ & $38.3^{\mathrm{bc}}$ & $38.5^{\mathrm{c}}$ & $38.6^{\mathrm{cd}}$ & $38.2^{\mathrm{a}}$ & $38.5^{\mathrm{c}}$ & NA \\
\hline NOMAS & $38.1^{\mathrm{ab}}$ & $38.7^{\mathrm{cd}}$ & $38.4^{\mathrm{bc}}$ & $38.4^{\mathrm{bc}}$ & $38.4^{\mathrm{ab}}$ & $38.2^{\mathrm{ab}}$ & $38.1^{\mathrm{ab}}$ & NA \\
\hline TRT-EST & $37.8^{\mathrm{a}}$ & $38.7^{\mathrm{cd}}$ & $38.6^{\text {cd }}$ & $38.7^{\mathrm{cd}}$ & $38.5^{\mathrm{c}}$ & $38.7^{\text {cd }}$ & $39.5^{\mathrm{de}}$ & NA \\
\hline TRT-NOEST & $37.8^{\mathrm{a}}$ & $39.1^{\mathrm{de}}$ & $38.4^{\mathrm{bc}}$ & $38.8^{\mathrm{d}}$ & $38.3^{\mathrm{bc}}$ & $38.2^{\mathrm{ab}}$ & $38.1^{\mathrm{ab}}$ & NA \\
\hline
\end{tabular}

${ }^{1} \mathrm{~d} 0$ = Day of bacterial challenge.

${ }^{2} \mathrm{CON}=$ Control (unchallenged) cows; NOMAS = cows challenged with Strep . uberis that did not develop mastitis; TRT-EST = cows that were challenged, became infected, and did display estrus; and TRT-NOEST = cows that were challenged, became infected, and did not display estrus.

${ }^{3}$ Mammary scores with different superscripts ( ${ }^{\mathrm{a}, \mathrm{b}, \mathrm{c}, \mathrm{d}, \mathrm{e}}$ ) differed (Pooled SEM $=0.27 P<0.0001$ ). Mammary scores were on a scale from 1 (no mastitis) to 5 (most severe mastitis).

${ }^{4} \mathrm{NA}=$ Data not available.

${ }^{5}$ Mean SCC of challenged quarters or control quarters $\left(\log _{10}\right.$ cells $/ \mathrm{mL}$; Pooled SEM $\left.=0.28\right) ;{ }^{\mathrm{a}, \mathrm{b}, \mathrm{c}, \mathrm{d}} \mathrm{SCC}$ differed $(P<0.0001)$.

${ }^{6}$ Rectal temperature $\left({ }^{\circ} \mathrm{C}\right.$; Pooled $\left.\mathrm{SEM}=0.26\right) ;{ }^{\mathrm{a}, \mathrm{b}, \mathrm{c}, \mathrm{d}}$ Rectal temperatures with different superscripts differed $(P=0.04)$.

\section{RESULTS}

Control cows that remained free of mammary infection $(\mathrm{n}=12)$, challenge cows that developed clinical mastitis before estrus expression $(\mathrm{n}=12)$, and cows that were inoculated with bacteria but failed to develop mastitis $(n=5)$ were used for data analysis. During the experiment, 2 control animals displayed signs of mastitis and were culled from the experiment. Furthermore, 2 cows that were challenged developed subclinical mastitis (1/replicate) and these animals were not used for statistical analysis of data due to low numbers. After removal of animals that did not comply with the experimental model, 29 cows remained. Following bacterial challenge, $100 \%$ of CON (12/12) cows and $80 \%$ of cows that did not display mastitis following challenge (NOMAS; 4/5) displayed estrus, whereas only $33 \%$ (4/12; $P$ $<0.0001$ ) of challenged cows displayed estrus. Within challenged cows that fit the model of developing mastitis before estrus, 2 populations existed. Therefore, challenged cows were further divided into those that displayed estrus (TRT-EST; $\mathrm{n}=4$ ) and those that did not display estrus (TRT-NOEST; $\mathrm{n}=8$ ). Animals within these different groups may be different and thus 4 classifications allowed for 4 "treatments" for analysis of data: 1) CON, 2) NOMAS, 3) TRT-EST, and 4) TRTNOEST.

\section{Clinical Assessment of Mastitis}

Mammary scores, an indicator of severity or absence of mastitis, were elevated in TRT-EST and TRTNOEST compared with control and NOMAS animals (Table $1 ; P<0.0001$ ). Following bacterial inoculation, mean SCC were higher in TRT-NOEST and TRT-EST than CON and NOMAS (Table $1 ; P=0.0009$ ). Severity scores of 4 within TRT-EST and TRT-NOEST resulted in higher SCC over the experimental period $(P<$ $0.0001)$. Somatic cell counts differed (increased) for treatment over days of the experiment (Table $1 ; P<$ 0.0001). Rectal temperatures were increased in TRTNOEST and TRT-EST on multiple days of the experiment compared with CON and NOMAS cows (Table 1; $P=0.04)$. Mean rectal temperatures were higher for TRT-EST cows $\left(38.9 \pm 0.2^{\circ} \mathrm{C}\right)$ and TRT-NOEST cows $\left(38.6 \pm 0.2^{\circ} \mathrm{C}\right)$ with a mastitis score of 4 than for those with a score of $2(38.4 \pm 0.2$ and $38.4 \pm 0.2$, respectively; $P=0.04)$.

\section{Events Associated with Estrus}

Because animals in the TRT-NOEST group did not display estrus, only data from CON, NOMAS, and TRTEST groups are reported for parameters associated with timing of events of estrus. Time from $\mathrm{PGF}_{2 \alpha}$ administra- 
Table 2. Events associated with estrus for unchallenged control cows, cows challenged with Strep. uberis that did not develop mastitis (NOMAS), cows that were challenged, became infected, and did display estrus (TRT-EST), and cows that were challenged, became infected, and did not display estrus (TRT-NOEST).

\begin{tabular}{|c|c|c|c|c|}
\hline \multirow[b]{2}{*}{ Parameter } & \multicolumn{4}{|c|}{ Treatment group } \\
\hline & $\mathrm{CON}$ & NOMAS & TRT-EST & TRT-NOEST \\
\hline $\mathrm{PGF}_{2 \alpha}$ to estrus ${ }^{1}$ & $91.5 \pm 6.1$ & $81.8 \pm 9.7$ & $84.3 \pm 11.2$ & $\mathrm{NA}^{2}$ \\
\hline Estrus to ovulation ${ }^{3}$ & $28.1 \pm 2.2$ & $27.6 \pm 2.9$ & $27.6 \pm 3.8$ & $\mathrm{NA}$ \\
\hline $\mathrm{PGF}_{2 \alpha}$ to LH surge ${ }^{4}$ & $88.0 \pm 5.9$ & $84.5 \pm 10.1$ & $93.2 \pm 9.1$ & NA \\
\hline $\mathrm{PGF}_{2 \alpha}$ to ovulation ${ }^{5}$ & $114.1 \pm 5.8$ & $113.2 \pm 9.7$ & $115.1 \pm 10.4$ & NA \\
\hline LH max value ${ }^{6}$ & $10.9 \pm 1.2^{\mathrm{a}}$ & $8.2 \pm 1.9^{\mathrm{a}}$ & $9.0 \pm 1.9^{\mathrm{a}}$ & $1.8 \pm 1.6^{\mathrm{b}}$ \\
\hline LH pulse frequency ${ }^{7}$ & $8.3 \pm 0.6^{\mathrm{a}}$ & $8.8 \pm 1.5^{\mathrm{a}}$ & $7.5 \pm 0.8^{\mathrm{a}}$ & $4.4 \pm 0.7^{\mathrm{b}}$ \\
\hline Follicle size $\mathrm{e}^{8}$ & $17.3 \pm 1.3^{\mathrm{a}}$ & $15.3 \pm 0.7^{\mathrm{a}}$ & $17.3 \pm 1.3^{\mathrm{a}}$ & $16.2 \pm 1.8^{\mathrm{a}}$ \\
\hline
\end{tabular}

\footnotetext{
${ }^{1}$ Mean time from $\mathrm{PGF}_{2 \alpha}$ injection until estrus (hours) did not differ between treatment groups $(P=0.66)$.

${ }^{2} \mathrm{NA}=$ Not available due to TRT-NOEST not displaying estrus or LH surge.

${ }^{3}$ Mean time from onset of estrus to ovulation (hours \pm standard error) did not differ between treatment groups $(P=0.97)$.

${ }^{4}$ Mean time from $\mathrm{PGF}_{2 \alpha}$ to $\mathrm{LH}$ surge (hours $\pm \mathrm{SE}$ ) did not differ between treatment groups $(P=0.81)$.

${ }^{5}$ Mean time from $\mathrm{PGF}_{2 \alpha}$ to ovulation (hours $\pm \mathrm{SE}$ ) did not differ between treatment groups $(P=0.94)$.

${ }^{6}$ Maximum concentration of $\mathrm{LH}$ observed during 2-h blood collection ( $\left.\mathrm{ng} / \mathrm{mL} \pm \mathrm{SE}\right)$; ${ }^{\mathrm{a}, \mathrm{b}}$ Concentrations with different superscripts differed $(P=0.0017)$.

${ }^{7}$ Mean number of pulses of LH during $8 \mathrm{~h}$ intensive blood collection (number/8 $\mathrm{h} \pm \mathrm{SE}$ ); ${ }^{\mathrm{a}, \mathrm{b}, \mathrm{c}}$ Concentrations with different superscripts differed $(P=0.0011)$.

${ }^{8}$ Mean follicle size $(\mathrm{mm} \pm \mathrm{SE})$ at ovulation $\left(\mathrm{CON}\right.$ or TRT-EST) or at $114 \mathrm{~h}$ post $\mathrm{PGF}_{2 \alpha}$ (TRT-NOEST) did not differ $(P=0.46)$.
}

tion to estrus, estrus to ovulation, $\mathrm{PGF}_{2 \alpha}$ to ovulation, and $\mathrm{PGF}_{2 \alpha}$ to $\mathrm{LH}$ surge were similar for CON, NOMAS, and TRT-EST (Table 2). Size of the ovulatory follicle did not differ between CON, NOMAS, TRT-EST, and TRT-NOEST (Table 2; $P=0.46$ ). However, ovulation rates were higher for CON (100\%), NOMAS (100\%), and TRT-EST (100\%) than for TRT-NOEST (0\%; Fisher's Exact Test: $P<0.0001)$.

\section{Hormones}

Concentrations of $\mathrm{P}_{4}$ were similar for all treatments throughout days of the experiment $(P=0.23)$. Progesterone declined for all treatments across day of experiment following $\mathrm{PGF}_{2 \alpha}$ administration $(P<0.0001$; data not shown). Concentrations of cortisol did not differ $(P=$ 0.37; data not shown) for any treatment group across days of the experiment. Mean concentrations of estradiol-17 $\beta$ during the $24 \mathrm{~h}$ period before LH maximum were significantly increased toward ovulation for $\mathrm{CON}$, NOMAS, and TRT-EST, whereas concentrations remained lower for TRT-NOEST (Figure $2 ; P<0.0001$ ).

Maximum observed value of LH (surge) was higher for CON, NOMAS, and TRT-EST than for TRT-NOEST (Table $2 ; P=0.0017$ ). Luteinizing hormone pulse frequency over the 8-h intensive sampling period (Table 2 ) was higher in CON, NOMAS, and TRT-EST animals than in TRT-NOEST animals $(P=0.001)$.

\section{Metabolic Parameters}

Serum NEFA, BUN, and insulin concentrations were similar $(P=0.11, P=0.85, P=0.14$, respectively; data not shown) for all treatments throughout the experimental period.

\section{DISCUSSION}

Cows in the current study became infected (infection rate: $12 / 19,63 \%$ ) with clinical mastitis following bacterial inoculation of Strep. uberis into 2 mammary quarters, consistent with previous studies (Hockett et al., 2000, 2002). Mean SCC, rectal temperatures, and mastitis scores were elevated in cows with clinical mastitis and remained low for control animals. Results of a study by Schrick et al. (2001) comparing cows with clinical and subclinical mastitis indicated similar detrimental effects of mastitis on reproductive performance. It should be noted that cows with clinical mastitis analyzed in this study (Schrick et al., 2001) received antibiotic therapy following onset of mastitis, whereas subclinical cows were not treated. Therefore, authors believe that antibiotic treatment $7 \mathrm{~d}$ following experimental challenge should not alter endocrine responses.

Estrus was observed to occur in all control cows and in 5/12 challenged cows that developed clinical mastitis. This rate is consistent with earlier studies that indicated that clinical mastitis resulted in decreased es- 


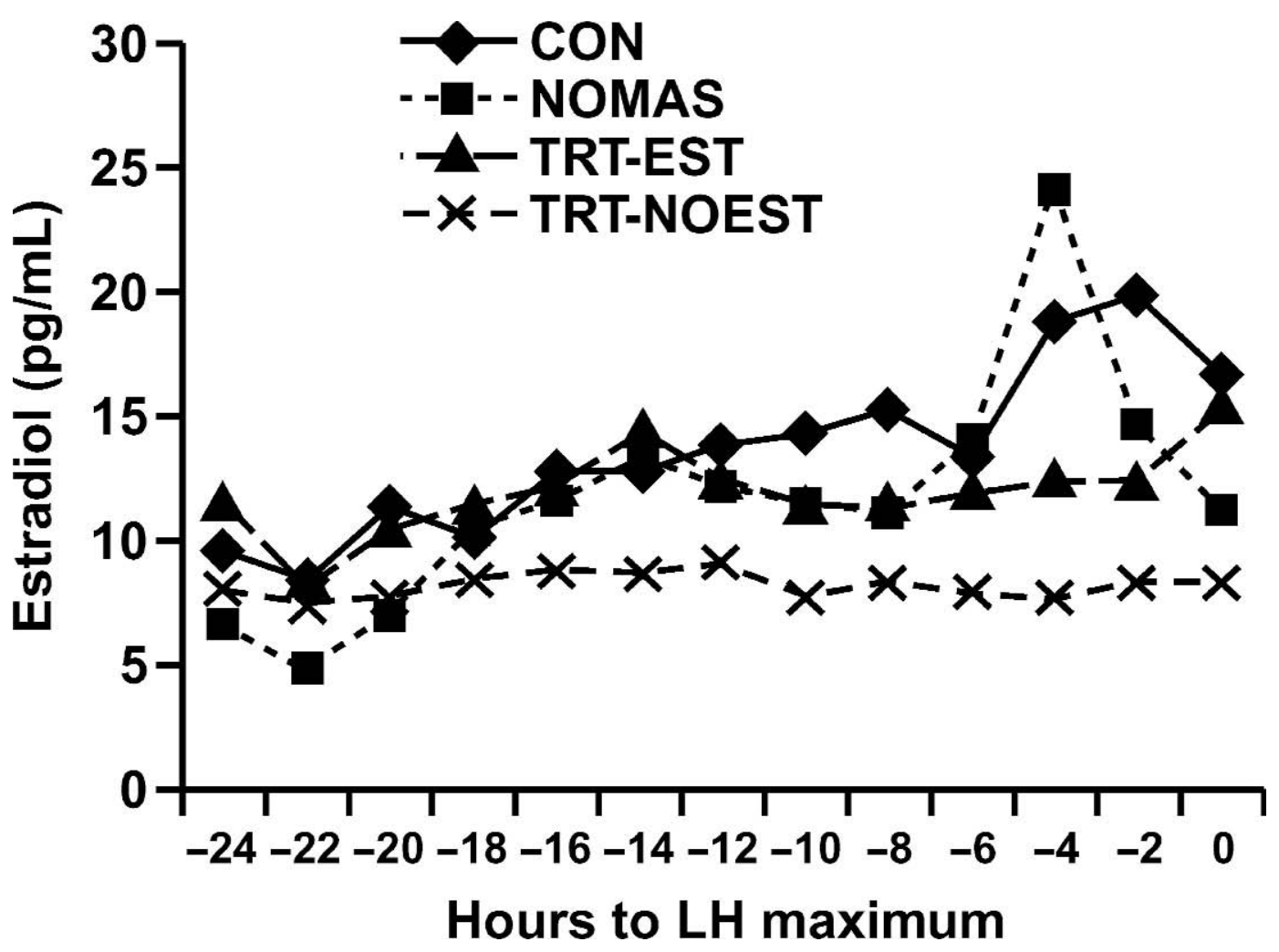

Figure 2. Serum concentrations of estradiol-17 $\beta$ during the 24-h period before LH surge. CON = Control (unchallenged) cows; NOMAS = cows challenged with Strep. uberis that did not develop mastitis; TRT-EST = cows that were challenged, became infected, and did display estrus; and TRT-NOEST = cows that were challenged, became infected, and did not display estrus.

trous expression within $8 \mathrm{~d}$ following $\mathrm{PGF}_{2 \alpha}$ administration (Hockett et al., 2002). Subdividing challenged cows with clinical mastitis into those that did and did not show estrus and challenged cows that did not exhibit signs of clinical mastitis resulted in 4 treatment groups for analyses of hormone data and parameters associated with estrus. These groups were subdivided to account for differences that may occur within different physiological states resulting in altered ability to display estrus or alterations that may occur following challenge in cows that did not develop clinical mastitis.

Time from $\mathrm{PGF}_{2 \alpha}$ to estrus, estrus to ovulation, and $\mathrm{PGF}_{2 \alpha}$ to ovulation were similar between CON, NOMAS, and TRT-EST. These data are not surprising as Hockett et al. (2002) reported that pregnancy occurred in mastitic cows that displayed estrus and were artificially inseminated. Cows with mastitis not displaying estrus following luteal regression would result in increased number of days to first service. This may explain similar associations between clinical mastitis, elevated days to first service, and increased days open reported previously (Barker et al., 1998; Schrick et al., 2001).
Decreased concentrations of estrogen observed in the current experiment are helpful to delineate the mechanism of decreased estrous expression observed by Hockett et al. (2002) in cows with clinical mastitis. Additionally, decreased expression of estrus and failed ovulation further explain increased days to first service associated with cows with clinical mastitis before first service (Barker et al., 1998; Schrick et al., 2001). Interestingly, follicle development was not different between the 4 groups of animals. However, LH pulse frequency was decreased in TRT-NOEST compared with CON cows, which had LH pulsatility similar to that reported by Rahe et al. (1980). Therefore, clinical mastitis immediately before ovulation has a negative impact on normal endocrine and follicular function.

Inflammatory or infectious diseases often result in stimulation of an immune response that interferes with LH function by releasing cytokines such as tumor necrosis factor- $\alpha$ or interleukins. Darbon et al. (1989) reported that tumor necrosis factor- $\alpha$ inhibited the stimulating action of FSH on $\mathrm{LH}$ receptor formation in cultured rat granulosa cells and had an inhibitory effect on FSH-induced cAMP production. Darbon et al. (1989) 
hypothesized that tumor necrosis factor- $\alpha$ released during infections might reduce ability of granulosa cells to differentiate upon FSH stimulation and to respond to $\mathrm{LH}$ because of alterations in LH receptors during follicle growth and maturation. Granulosa cells are important for production of estrogens that subsequently influence LH production.

Cytokines such as interleukins are key mediators associated with effects of gram-negative and gram-positive bacteria (Nathan, 1987; Zerbe et al., 2001). Zerbe et al. (2001) reported that gram-positive and gram-negative bacteria have similar effects on polymorphonuclear granulocyte function in vitro. McCann et al. (1997) reported that IL-1, normally released during infection, blocks the pulsatile secretion of $\mathrm{LH}$, but not FSH, through alterations in nitric oxide production to inhibit GnRH. Furthermore, IL-1 disrupts normal estrous cyclicity, GnRH gene expression, and LH and FSH secretion (Rivest et al., 1993). Interleukin-6 is a cytokine produced by macrophages during immune response and is a potent inhibitor of proliferation and FSH-induced $\mathrm{E}_{2}$ production from small and large follicles in vitro (Alpizar and Spicer, 1994). Cows in the current experiment that did not display estrus had decreased concentrations of estradiol-17 $\beta$ following luteal regression; however, follicular size was similar in all groups. Release of inflammatory mediators and cytokines during the immune response may alter the ability of GnRH to signal gonadotropin release and subsequently for gonadotropins that are released to transduce signals required for normal production of estrogens. Pulsatility of LH may be decreased as a secondary response of decreased estrogen production.

Intravenous endotoxin infusion interrupted the preovulatory rise of estradiol and delayed or completely blocked the preovulatory LH surge, decreased LH pulsatility, and suppressed expression of estrus in ewes (Battaglia et al., 1999). A subsequent study (Battaglia et al., 2000) reported that low doses of endotoxin were sufficient to slightly decrease GnRH release, yet LH pulses were completely inhibited in some animals. Therefore, activation of the immune system may alter GnRH release from the hypothalamus and hinder the ability of the pituitary to respond to GnRH signals. In fact, administering exogenous $\mathrm{GnRH}$ while blocking endogenous GnRH during endotoxin infusion in sheep resulted in decreased amplitude of LH pulses. Endotoxin and clinical mastitis caused by Strep. uberis may have similar modes of action through release of cytokines and less of a direct action upon the endocrine system themselves.

Data support cortisol as having the major negative impact on normal follicular growth and endocrine function. However, cortisol concentrations did not appear to be elevated in the current study. More frequent sampling of cortisol and sampling over time may be necessary to properly determine alterations which occur in free cortisol. Stressful conditions associated with mastitis and activation of the immune response have resulted in increased concentrations of cortisol. For example, ewes treated with endotoxin had significantly lower $\mathrm{GnRH}$ pulse amplitude, lower concentrations of $\mathrm{GnRH}$ and LH, elevated concentrations of cortisol and progesterone, and elevated body temperature (Battaglia et al., 1997). Peter et al. (1989) reported that cycling heifers that received intrauterine infusion of endotoxin had elevated cortisol concentrations and smaller follicles on d 12 of the estrous cycle. Peter et al. (1989) also observed that follicles that failed to ovulate from $\mathrm{PGF}_{2 \alpha}$-induced luteal regression resulted in cysts, which persisted for 7 to $21 \mathrm{~d}$. Formation of follicular cysts on ovaries could result from cortisol suppression of the LH surge (LopezDiaz and Bosu, 1992). In a previous study, cortisol was increased and expression of estrus was delayed up to 21 $d$ in cows with experimentally induced clinical mastitis before estrus (Hockett et al., 2002). More directly, infusion of cortisol in ewes decreased follicular development and the ovulatory surge of LH was absent (Macfarlane et al., 2000). When cortisol infusion ceased, follicular development returned to normal, and LH surge occurred. Daley et al. (1999) reported that infusion of cortisol in sheep blocked the LH surge in 54\% of sheep and estrus either did not occur or was delayed. A similar percentage of cows with clinical mastitis displayed estrus in the current study. Animals that did not display estrus had no apparent LH surge during the intensive sampling period and LH pulsatility decreased to onehalf that of control cows.

There were no observed alterations in metabolic parameters in the current study for any group of cows. These data suggest that previous finding of changes in metabolic parameters might be due to longer periods of evaluation following onset of clinical mastitis. In the present study, cows were monitored and samples were collected for approximately $10 \mathrm{~d}$ following challenge. Decreased feed intake of animals during clinical mastitis may lead to negative energy balance and subsequent decreased reproductive performance through changes in uterine environment and $\mathrm{PGF}_{2 \alpha}$ release. Feed intake was monitored in the current study with large daily variations occurring within and between cows. Conclusions about feed intake would require more animals than available in this trial and conclusions cannot be made concerning energy balance of mastitic cows.

\section{CONCLUSIONS}

Previous studies have indicated that cows with clinical mastitis had decreased expression of estrus and 
increased number of days until estrus (Hockett et al., 2002). The current study was performed to determine how clinical mastitis affected endocrine function, particularly communication from the pituitary to the ovary. Results of the current study suggest that clinical mastitis has multiple actions that hinder normal endocrine function. Luteinizing hormone pulsatility was greatly reduced, and subsequently, estradiol-17 $\beta$ production was decreased in some animals resulting in a lack of estrous expression. This may explain why the LH surge was absent in cows with acute clinical mastitis and why ovulation was blocked. Future studies should be aimed to determine the causative agents behind suppression of LH, estradiol- $17 \beta$, and the potential role of the hypothalamus in control of the hypothalamopituitary-ovarian axis during clinical infection.

\section{ACKNOWLEDGMENTS}

The authors extend special appreciation to American Jersey Cattle Research Foundation for partial sponsorship of this research. The authors appreciate the vast amount of assistance from personnel at the Dairy Experiment Station, especially Hugh Moorehead and Phil Lunn for their help in data collection and management of the cattle. Further acknowledgment is needed of the large number of graduate and undergraduate students who assisted in the study, especially Heather Blackmon and Fernando Scenna.

\section{REFERENCES}

Alpizar, E., and L. J. Spicer. 1994. Effects of interlaukin-6 on proliferation and follicle-stimulating hormone-induced estradiol production by bovine granulosa cells in vitro: Dependence on size of follicle. Biol. Reprod. 50:38-43.

Barker, A. R., F. N. Schrick, M. J. Lewis, H. H. Dowlen, and S. P. Oliver. 1998. Influence of clinical mastitis during early lactation on reproductive performance of Jersey cows. J. Dairy Sci. $81: 1285-1290$.

Battaglia, D. F., A. B. Beaver, T. G. Harris, E. Tanhehco, C. Virguie, and F. J. Karsch. 1999. Endotoxin disrupts the estradiol-induced luteinizing hormone surge: Interference with estradiol signal reading, not surge release. Endocrinology 140:2471-2479.

Battaglia, D. F., J. M. Bowen, H. B. Krasa, L. A. Thrun, C. Viguie, and F. J. Karsch. 1997. Immune stress and reproductive neuroendocrine function: Physiologic evidence for profound inhibition of GnRH secretion. Biol. Reprod. 54(Suppl. 1):93.

Battaglia, D. F., H. B. Krasa, V. Padmanabhan, C. Viguie, and F. J. Karsch. 2000. Endocrine alterations that underlie endotoxininduced disruption of the follicular phase in ewes. Biol. Reprod. 62:45-53.

Cullor, J. S. 1990. Mastitis and its influence upon reproductive performance in dairy cattle. Pages 176-180 in Proc. Int. Symp. Bovine Mastitis, Indianapolis, IN. Natl. Mastitis Counc., Inc., and Am. Assoc. Bovine Pract., Arlington, VA.

Daley, C. A., M. S. Macfarlane, H. Sakurai, and T. E. Adams. 1999. Effect of stress-like concentrations of cortisol on follicular development and the preovulatory surge of LH in sheep. J. Reprod. Fertil. 117:11-16.
Darbon, J. M., F. Oury, J. Laredo, and F. Bayard. 1989. Tumor necrosis factor-alpha inhibits follicle-stimulating hormone-induced differentiation in cultured rat granulosa cells. Biochem. Biophys. Res. Commun. 163:1038-1046.

DeGraves, F. J., and F. Fetrow. 1993. Economics of mastitis and mastitis control. Update on bovine mastitis. Vet. Clin. North. Am. Food Anim. Pract. 9:421-434.

Fazio, R. A., M. E. Hockett, J. L. Edwards, N. R. Rohrbach, and F. N. Schrick. 1999. Effect of body condition and/or pregnancy status on developmental potential of bovine oocytes. Theriogenology $51: 223$.

Hockett, M. E., F. M. Hopkins, M. J. Lewis, A. M. Saxton, H. H. Dowlen, S. P. Oliver, and F. N. Schrick. 2000. Endocrine profiles following experimentally induced clinical mastitis during early lactation. Anim. Reprod. Sci. 58:241-251.

Hockett, M. E., N. R. Rohrbach, R. A. Almeida, H. H. Dowlen, K. Lamar, S. P. Oliver, and F. N. Schrick. 2002. Effects of experimentally-induced clinical mastitis on estrous behavior, luteal function, and establishment of pregnancy during early lactation of dairy cows. J. Anim. Sci 80(Suppl. 1)/J. Dairy Sci. 85(Suppl. 1):264. (Abstr.)

Knopf, L., J. P. Kastelic, E. Schallenberger, and O. J. Ginter. 1989. Ovarian follicular dynamics in heifers: Test of two-wave hypothesis by ultrasonically monitoring individual follicles. Domest. Anim. Endocrinol. 6:111-119.

Lopez-Diaz, M. C., and W. T. K. Bosu. 1992. A review and update of cystic ovarian degeneration in ruminants. Theriogenology 37:1163-1183.

Macfarlane, M. S., K. M. Breen, H. Sakurai, B. M. Adams, and T. E. Adams. 2000. Effect of duration of infusion of stress-like concentrations of cortisol on follicular development and the preovulatory surge of LH in sheep. Anim. Reprod. Sci. 63:167-175.

McCann, S. M., M. Kimura, S. Karanth, W. H. Yu, and V. Rettori. 1997. Nitric oxide controls the hypothalamic-pituitary response to cytokines. Neuroimmunomodulation 4:98-106.

Moore, D. A., J. S. Cullor, R. H. Bon Durant, and W. M. Sischo. 1991. Preliminary field evidence for the association of clinical mastitis with altered interestrus intervals in dairy cattle. Theriogenology $36: 257-265$

Moore, D. A., and M. L. O'Connor. 1993. Coliform mastitis: Its possible effects on reproduction in dairy cattle. Pages 162-166 in Proc. Natl. Mastitis Counc., Kansas City, MO. Natl. Mastitis Counc., Inc., Arlington, VA.

Moura, A. A., and B. H. Erickson. 1997. Age-related changes in peripheral hormone concentrations and their relationships with testis size and number of Sertoli and germ cells in yearling beef bulls. J. Reprod. Fertil. 111:183-190.

Nathan, C. F. 1987. Neutrophil activation on biological surfaces. Massive secretion of hydrogen peroxide in response to products of macrophages and lymphocytes. J. Clin. Invest. 80:1550-1560.

Oliver, S. P., B. E. Gillespie, M. J. Lewis, T. L. Ingle, and H. H. Dowlen. 1994. Evaluation of chlorhexidine as a premilking teat disinfectant for the prevention of intramammary infections during lactation. J. Food Prot. 57:614-618.

Peter, A. T., W. T. K. Bosu, and R. J. DeDecker. 1989. Suppression of preovulatory luteinizing hormone surges in heifers after intrauterine infusions of Escherichia coli endotoxin. Am. J. Vet. Res. $50: 369-373$.

Rahe, C. H., R. E. Owens, J. L. Fleeger, H. J. Newton, and P. G. Harms. 1980. Pattern of plasma luteinizing hormone in the cyclic cow: Dependence upon the period of the cycle. Endocrinology 107:498-503.

Rivest, S., S. Lee, B. Attardi, and C. Rivier. 1993. The chronic intracerebroventricular infusion of interleukin-1 beta alters the activity of the hypothalamic-pituitary-gonadal axis of cycling rats. I. Effect on LHRH and gonadotropin biosynthesis and secretion. Endocrinology 133:2424-2430.

SAS Institute. 1996. SAS User's Guide: Statistics. Version 6.12. SAS Inst., Inc., Cary, NC. Schrick, F. N., M. E. Hockett, A. M. Saxton, M. J. Lewis, H. H. Dowlen, and S. P. Oliver. 2001. Influence of subclinical mastitis during early lactation on reproductive parameters. J. Dairy Sci. 84:1407-1412. 
Schrick, F. N., J. C. Spitzer, T. C. Jenkins, D. M. Henricks, and T. G. Althern. 1990. Effect of dietary energy restriction on metabolic and endocrine responses during the estrous cycle of the suckled beef cow. J. Anim. Sci. 68:3313-3321.

Seals, R. C., J. W. Lemaster, F. M. Hopkins, and F. N. Schrick. 1998. Effects of elevated concentrations of $\mathrm{PGF}_{2 \alpha}$ on early embryonic survival in progestogen supplemented cattle. Prostaglandins $56: 377-389$
Seals, R. C., F. N. Schrick, F. M. Hopkins, J. C. Waller, and H. A. Fribourg. 1996. Follicular dynamics in heifers administered ergotamine tartrate (ET) as a model of endophyte-infected tall fescue consumption. J. Anim. Sci. 74(Suppl. 1):11.

Zerbe, H., C. Ossadnik, W. Leibold, and H. J. Schuberth. 2001. Influence of Escherichia coli and Arcanobacterium pyogenes isolated from bovine puerperal uteri on phenotypic and functional properties of neutrophils. Vet. Microbiol. 79:351-365. 